\title{
Role of Discrimination Indices in Screening of Beta Thalassemia Trait in Low-Resourced Areas of Pakistan
}

\author{
Asma Mustafa*, Bushra Anam Ali, Maryam Zulfiqar, Lubna Naseem \\ Department of Hematology, Pakistan Institute of Medical Sciences, Islamabad, Pakistan.
}

\begin{abstract}
Introduction: Thalassemia is a common inherited hemoglobinopathy in Pakistan. Despite various preventive measures taken, each year around 5000 new cases are diagnosed. The problem occurs due to undiagnosed beta Thalassemia carriers. This is because of lack of massive screening programs and unavailability of hemoglobin electrophoresis in different cities of Pakistan. The aim of this study is to assess the sensitivity of different discriminating indices in screening of beta Thalassemia trait.
\end{abstract}

Material and Methods: The study was conducted at Pakistan Institute of Medical Sciences from January 2018-July 2018. All patients who were diagnosed as beta thalassemia trait through hemoglobin electrophoresis were included in the study. Seven discriminating indices were applied and sensitivity of each index was calculated.

Results: The male to female ratio was $1: 1.88 \%$ of the cases had a positive family history of Thalassemia. Among the various indices used, Shine and Lal showed a sensitivity of 100\%, followed by Ricerca (96.6\%) and Ehsani (92.58\%). The sensitivities of Mentzer, Srivasta, RDWI and MCHD were $92.56 \%, 91.70 \%, 79 \%$ and $70.9 \%$ respectively. The results of our study showed that Shine and Lal is the most sensitive index for screening beta Thalassemia trait.

Conclusion: Shine and Lal index is useful to the clinicians as an initial screening tool of beta thalassemia trait. Such cases can then be referred to laboratories where hemoglobin electrophoresis facility is available.

Keywords: Beta Thalassemia, Thalassemia trait, Discriminating indices, Iron deficiency anemia, Microcytic hypochromic anemia, Hemoglobin electrophoresis,

\section{INTRODUCTION}

Beta Thalassemia is a genetic disorder in which hemoglobin synthesis is impaired. It has an autosomal recessive pattern of inheritance which can result into homozygous state called beta Thalassemia Major or heterozygous state known as Beta Thalassemia trait. Thalassemia is prevalent worldwide. It is estimated that around $3 \%$ of the whole world population carries the mutated for Thalassemia. Each year 60,000 babies are born with Thalassemia of which $80 \%$ burden is mainly on the Asian countries [1]. In Pakistan, 5000 cases are diagnosed with Thalassemia every year. The carrier rate in our country is $5-8 \%$ [2].

The diagnostic test for Thalassemia is Hemoglobin electrophoresis. However, complete blood picture may also be rendered useful for early screening of Thalassemia trait. Microcytic hypochromic Anemia is usually present with Mean Corpuscular Volume $(\mathrm{MCV})$ of $<75 \mathrm{fL}$, Mean Corpuscular Hemoglobin $(\mathrm{MCH})$ of $<25 \mathrm{pg}$ and Red blood cell count of $>5$ million $/ \mu$ L [3]. However, microcytic hypochromic Anemia is also a feature of iron deficiency Anemia therefore diagnosing Thalassemia trait on blood picture is challenging.

*Address correspondence to this author at the Department of Hematology Pakistan Institute of Medical Sciences, Islamabad, Pakistan.

E-mail: asmamustafa87@gmail.com
More than 40 discrimination indices have been reported in literature to differentiate between beta Thalassemia and Iron deficiency anemia however, some of them are based on complex mathematical formulas [4]. It is therefore important that the discrimination index is based on simple formula which can easily be memorized and calculated without the need of a calculator. The aim of this study was to find the sensitivity of most commonly used discriminating indices.

\section{MATERIAL AND METHODS}

The study was conducted in the Pathology Department of Pakistan Institute of Medical Sciences (PIMS) from January 2018 till July 2018. A total of 121 patients, who were referred to us for hemoglobin electrophoresis and those which were diagnosed as Beta Thalassemia trait were analysed. HbA2 value of $>3.5 \%$ was considered as diagnostic for Beta Thalassemia trait. Pregnant females and patients with history of recent transfusion were excluded.

Seven discrimination indices based on simple mathematics were applied to all cases which were diagnosed with beta thalassemia trait on hemoglobin electrophoresis. These include Mentzer Index [5], Srivastava Index [6], Sine and Lal Index [7], RDW Index [8], Ricerca Index [9], Mean cell hemoglobin density (MCHD) [10] and Ehsani Index [11]. 
The calculation and critical values of these indices are mentioned below in Table $\mathbf{1}$.

Table 1. The Discrimination Indices with Cut Off Values.

\begin{tabular}{|c|c|c|c|c|}
\hline No. & Name & Formula & Cut off for $\boldsymbol{\beta T T}$ & Cut off for IDA \\
\hline 1 & Mentzer Index [5] & MCV/RBC & $<13$ & $>13$ \\
\hline 2 & Srivastava [6] & MCH/RBC & $<3.8$ & $>3.8$ \\
\hline 3 & Shine and lal [7] & MCV2 $\times$ MCH/100 & $<1530$ & $>1530$ \\
\hline 4 & RDW Index [8] & MCV $\times$ RDW/RBC & $<220$ & $>220$ \\
\hline 5 & Ricerca [9] & RDW/RBC & $<4.4$ & $>4.4$ \\
\hline 6 & MCHD [10] & MCH/MCV & $<0.3045$ & $>0.3045$ \\
\hline 7 & Ehsani [11] & MCV $-(10 \times \mathrm{RBC})$ & $<15$ & $>15$ \\
\hline
\end{tabular}

BTT: Beta Thalassemia trait, IDA: Iron deficiency Anemia, RDW: Red cell distribution width, MCHD: Mean cell hemoglobin density.

The sensitivity of each index was calculated by putting in true positive and false negative cases in the following formula:

Sensitivity $=\frac{\text { True positive }}{\text { True positive }+ \text { False negative }}$

\section{RESULTS}

The age range was 7 months- 42 years, out of which 61 were males and 60 were females. Out of 121 cases, $106(88 \%)$ had a positive family history of Thalassemia while the remaining $15(12 \%)$ cases gave no history of known Thalassemia patient in the family. The results of complete Blood Picture of these cases is given in Table 2, showing the mean values with standard deviation and minimum and maximum range of the parameter obtained.

Table 2. The Complete Blood Picture Report of Beta Thalassemia Patients.

\begin{tabular}{|c|c|c|c|}
\hline No. & Hematological Parameters & Mean \pm SD & Range (Min-Max) \\
\hline 1 & Total Leucocyte Count $\left(\times 10^{3} / \mu \mathrm{L}\right)$ & $9.2 \pm 2.3$ & $4.5-15$ \\
\hline 2 & Red Blood Cell Count $\left(\times 10^{6} / \mu \mathrm{L}\right)$ & $5.8 \pm 0.6$ & $4.5-7.5$ \\
\hline 3 & Hemoglobin $(\mathrm{g} / \mathrm{dL})$ & $11 \pm 1.7$ & $5.1-13$ \\
\hline 4 & Hematocrit $(\%)$ & $37 \pm 4.8$ & $23-49$ \\
\hline 5 & Mean Corpuscular Volume $(\mathrm{fL})$ & $62.9 \pm 4.41$ & $50.7-77.9$ \\
\hline 6 & Mean Corpuscular Hemoglobin $(\mathrm{pg})$ & $19 \pm 2$ & $11-25$ \\
\hline 7 & Mean Corpuscular Hemoglobin Concentration $(\mathrm{g} / \mathrm{dL})$ & $29.7 \pm 1.4$ & $169-871$ \\
\hline 8 & Platelet Count $\left(\times 10^{3} / \mu \mathrm{L}\right)$ & $358 \pm 129$ & $0.2-7.2$ \\
\hline 9 & Reticulocyte Count $(\%)$ & $1.9 \pm 1.4$ & \\
\hline
\end{tabular}

The results of the discriminating indices showing true positive and false negative cases is mentioned below in Table 3 .

Table 3. Sensitivity of Discriminating Indices $(n=121)$.

\begin{tabular}{|c|c|c|c|c|}
\hline No. & Name & True Positive (n) & False Negative (n) & Sensitivity (\%) \\
\hline 1 & Mentzer Index & 112 & 09 & 92.56 \\
\hline 2 & Srivastava & 111 & 10 & 91.70 \\
\hline 3 & Shine and lal & 100 & 0 & 100 \\
\hline 4 & RDW Index & 96 & 25 & 79 \\
\hline 5 & Ricerca & 117 & 4 & 96.6 \\
\hline 6 & MCHD & 85 & 36 & 70.2 \\
\hline 7 & Ehsani & 112 & 9 & 92.58 \\
\hline
\end{tabular}


Table 4. Comparison of Sensitivity of Discriminating Indices in Other Studies.

\begin{tabular}{|c|c|c|c|c|c|c|c|c|}
\hline \multirow{2}{*}{ No. } & \multirow[t]{2}{*}{ Name of study (Year) } & \multicolumn{7}{|c|}{ Sensitivity Of Indices (\%) } \\
\hline & & Mentzer & Srivastava & Shine and Lal & RDWI & Ricerca & MCHD & Ehsani \\
\hline 1. & $\begin{array}{l}\text { Vehapoglu } \\
\text { et al. }(2014) \text { [12] }\end{array}$ & 98.7 & 85.7 & 100 & 83.1 & 100 & 77.9 & 94.8 \\
\hline 2. & Tari et al. (2015) [13] & 92.5 & - & 81.25 & - & - & - & - \\
\hline 3. & $\begin{array}{c}\text { Bordbar } \\
\text { et al. }(2015)[14]\end{array}$ & 75.7 & 73.4 & 87.6 & - & - & - & 79.5 \\
\hline 3. & Zahid et al. (2016) [15] & 83 & 80 & 100 & 100 & - & - & - \\
\hline 4. & Ehsani et al. (2009) [16] & 95.5 & 85.7 & - & - & - & - & 95.5 \\
\hline 5. & Khan et al. (2018) [16] & 52 & 46 & 95 & 2 & - & - & - \\
\hline 6. & Kumar et al. (2017) [17] & 76.7 & 79.1 & 97.7 & 67.4 & 65.1 & - & - \\
\hline 7. & $\begin{array}{c}\text { Mukhopadhyay et al. } \\
(2015)[18]\end{array}$ & 57.3 & 52.5 & 96.4 & 63.0 & - & -- & \\
\hline 8. & Roth et al. (2018) [19] & 75.54 & 62.84 & 98.74 & - & - & - & 75.07 \\
\hline 9. & Present study & 92.56 & 91.70 & 100 & 79 & 96.6 & 70.9 & 92.58 \\
\hline
\end{tabular}

- Blank spaces indicate that index was not applied in that particular study.

\section{DISCUSSION}

According to our study, Shine and Lal showed the highest sensitivity, followed by Ricerca and Ehsani Indices. Almost similar results were obtained in studies done in our local population and other Asian region countries.

Table 4 shows the comparison of sensitivity of the discrimination indices in various studies. Vehapoglu et al. [12], Bordbar et al. [14], Zahid et al. [15], Khan et al. [16], kumar et al. [17], Mukhopadhyay et al. [18] and Roth et al. [19] found Shine and Lal index to be the most sensitive. Only Vehagpolu et al. and Zahid et al. found $100 \%$ sensitivity for Shine and Lal index, similar to our findings.

In the studies done by Tari et al. [13] and Ehsani et al. [11], Mentzer Index showed the highest sensitivity. Shine and Lal was not applied in the later. Zahid et al also found RDWI to have $100 \%$ sensitivity which was also evident in the study done by Jameel et al. [20] and Niazi et al. [21]. It is also considered more reliable as compared to RDW alone [22]. In another recent study, Ricerca Index was found to be highly sensitive [23].

A meta-analysis done by Hoffmann et al. also stated the combined sensitivity of these indices. According to their report, the highest sensitivity was of Shine and Lal (96\%), followed by Ricerca (93\%). Mentzer showed sensitivity of $82 \%$, Srivastava 78\%, Ehsani 91\%, and RDWI 62\% [4].

In a recent study by Sirdah et al., it was found that the RBC indices show variation when applied to males and females. The highest sensitivity was found for Srivastava Index which was $78.20 \%$ in case of male patients $(n=400)$ and $95.58 \%$ for female patients. $(n=400)$. This could also be a possible explanation of variable results obtained in different studies. In our study equal numbers of male and female patients were taken to exclude this difference [24].

It is also worth consideration that $12 \%$ cases from our study did not give any positive history of Thalassemia in the family. Therefore, in a country like ours, where hemoglobin electrophoresis is not readily available in all cities, it is very essential for the clinicians to carefully see the complete blood picture with special emphasis on RBC indices. A simple discriminating index such as Shine and Lal may be very useful in the initial screening of Beta Thalassemia trait. Such cases may then be referred to advanced clinical laboratories where the facility of hemoglobin electrophoresis is available.

\section{CONCLUSION}

Among various indices, Shine and Lal Indice shows the highest sensitivity. These discriminating indices are very useful tool in screening of Beta Thalassemia, especially in developing countries where hemoglobin electrophoresis is not readily available in every laboratory.

\section{CONFLICT OF INTEREST}

Declared none.

\section{ACKNOWLEDGEMENTS}

Declared none.

\section{REFERENCES}

[1] Asif N, Hassan K. Management of Thalassemia in Pakistan. JIMDC 2016; 5(4): 152-3.

[2] Ansari SH, Shamsi TS. Thalassaemia prevention programme. Haematol Updates 2010; 2010: 23-8.

[3] Qazi RA. Screening for Beta Thalassemia trait. J Rawalpindi Med Coll 2014; 18(1): 158-60.

[4] Hoffmann JJ, Urrechaga E, Aguirre U. Discriminant indices 
for distinguishing thalassemia and iron deficiency in patients with microcytic anemia: A meta-analysis. Clin Chem Lab Med 2015; 53(12): 1883-94. DOI: 10.1515/cclm-2015-0179

[5] Mentzer W. Differentiation of iron deficiency from thalassemia trait. Lancet 1973; 301(7808): 882.

DOI: $10.1016 / \mathrm{S} 0140-6736(73) 91446-3$

[6] Schriever H, Srivastava PC. Differentiation of Thalassemia minor from iron deficiency. Lancet 1973; 302(7821): 154-5. DOI: 10.1016/S0140-6736(73)93104-8

[7] Shine I, Lal S. A strategy to detect Beta Thalassemia minor. Lancet 1977; 309(8013): 692-4. DOI: $10.1016 / \mathrm{S} 0140-6736(77) 92128-6$

[8] Jayabose S, Giamelli J, LevondogluTugal O, Sandoval C, Ozkaynak F, Visintainer P. \# 262 Differentiating iron deficiency anemia from thalassemia minor by using an RDW-based index. J Pediatr Hematol Oncol 1999; 21(4): 314.

DOI: $10.1097 / 00043426-199907000-00040$

[9] Ricerca BM, Storti S, d'Onofrio G, et al. Differentiation of iron deficiency from thalassaemia trait: A new approach. Haematologica 1987; 72(5): 409-13.

[10] Telmissani OA, Khalil S, Roberts GT. Mean density of hemoglobin per liter of blood: A new hematologic parameter with an inherent discriminant function. Lab Hematol 1999; 5: 149-52.

[11] Ehsani MA, Shahgholi E, Rahiminejad MS, Seighali F, Rashidi A. A new index for discrimination between iron deficiency anemia and beta-thalassemia minor: Results in 284 patients. Pak J Biol Sci 2009; 12(5): 473.

DOI: $10.3923 /$ pjbs.2009.473.475

[12] Vehapoglu A, Ozgurhan G, Demir AD, et al. Hematological indices for differential diagnosis of beta thalassemia trait and iron deficiency anemia. Anemia 2014; 2014: Article ID 576738.

[13] Tari K, Atashi A, Karami F, Kiani Nodeh F, Shahjahani M. Evaluation of the formulae based on red blood cell indices in differentiating between iron deficiency anemia and Beta Thalasemia minor. IJML 2015; 2 (3): 188-93

[14] Bordbar E, Taghipour M, Zucconi BE. Reliability of different $\mathrm{RBC}$ indices and formulas in discriminating between beta thalassemia minor and other microcytic hypochromic cases. Mediterr J Hematol Infect Dis 2015; 7(1): e2015022.

DOI: $10.4084 /$ mjhid.2015.022
[15] Ullah Z, Khattak AA, Ali SA, et al. Evaluation of five discriminating indexes to distinguish Beta-Thalassemia trait from iron deficiency anaemia. JPMA 2016; 66(12): 1627-31.

[16] Khan MI, Khan HN, Usman M. Beta Thalassemia trait; diagnostic importance of haematological indices in detecting Beta Thalassemia Trait patients. Prof Med J 2018; 25(4): 545-50. DOI: 10.29309/TPMJ/18.4347

[17] Kumar A, Saha D, Kini J, Murali N, Chakraborti S, Adiga D. The role of discriminant functions in screening Beta Thalassemia trait and iron deficiency anemia among laboratory samples. J Lab Physicians 2017; 9(3): 195.

DOI: $10.4103 / 0974-2727.208256$

[18] Mukhopadhyay D, Saha K, Sengupta M, Mitra S, Datta C, Mitra PK. Role of discrimination indices in screening of Beta Thalassemia trait in West Bengal, India: An institutional experience on 10,407 subjects. Saudi J Health Sci 2015; 4(3): 151. DOI: $10.4103 / 2278-0521.171430$

[19] Roth IL, Lachover B, Koren G, Levin C, Zalman L, Koren A. Detection of Beta Thalassemia carriers by red cell parameters obtained from automatic counters using mathematical formulas. Mediterr J Hematol Infect Dis 2018; 10(1): e2018008. DOI: $10.4084 /$ mjhid.2018.008

[20] Jameel T, Baig M, Ahmed I, Hussain MB, bin Doghaim Alkhamaly M. Differentiation of Beta Thalassemia trait from iron deficiency anemia by hematological indices. Pak J Med Sci 2017; 33(3): 665. DOI: 10.12669/pjms.333.12098

[21] Niazi M, Tahir M, F Raziq, Hameed A. Usefulness of red cell indices in differentiating microcytic hypochromic anemias. GJMS 2010; 8(2): 125-9.

[22] Jameel T, Baig M, Ahmed I, Hussain MB, bin Doghaim Alkhamaly M. Differentiation of Beta Thalassemia trait from iron deficiency anemia by hematological indices. Pak J Med Sci 2017; 33(3): 665-69. DOI: 10.12669/pjms.333.12098

[23] Plengsuree S, Punyamung M, Yanola J, et al. Red cell indices and formulas used in differentiation of Beta Thalassemia trait from iron deficiency in Thai adults. Hemoglobin 2015; 39(4): 235-9. DOI: 10.3109/03630269.2015.1048352

[24] Sirdah M, Al Mghari K, Abuzaid AH, Al Haddad RM. Should sex differences be considered when applying mathematical indices and formulas for discriminating Beta Thalassemia minor from iron deficiency?. Pract Lab Med 2018; 11: 1-9. DOI: 10.1016/j.plabm.2018.01.004 